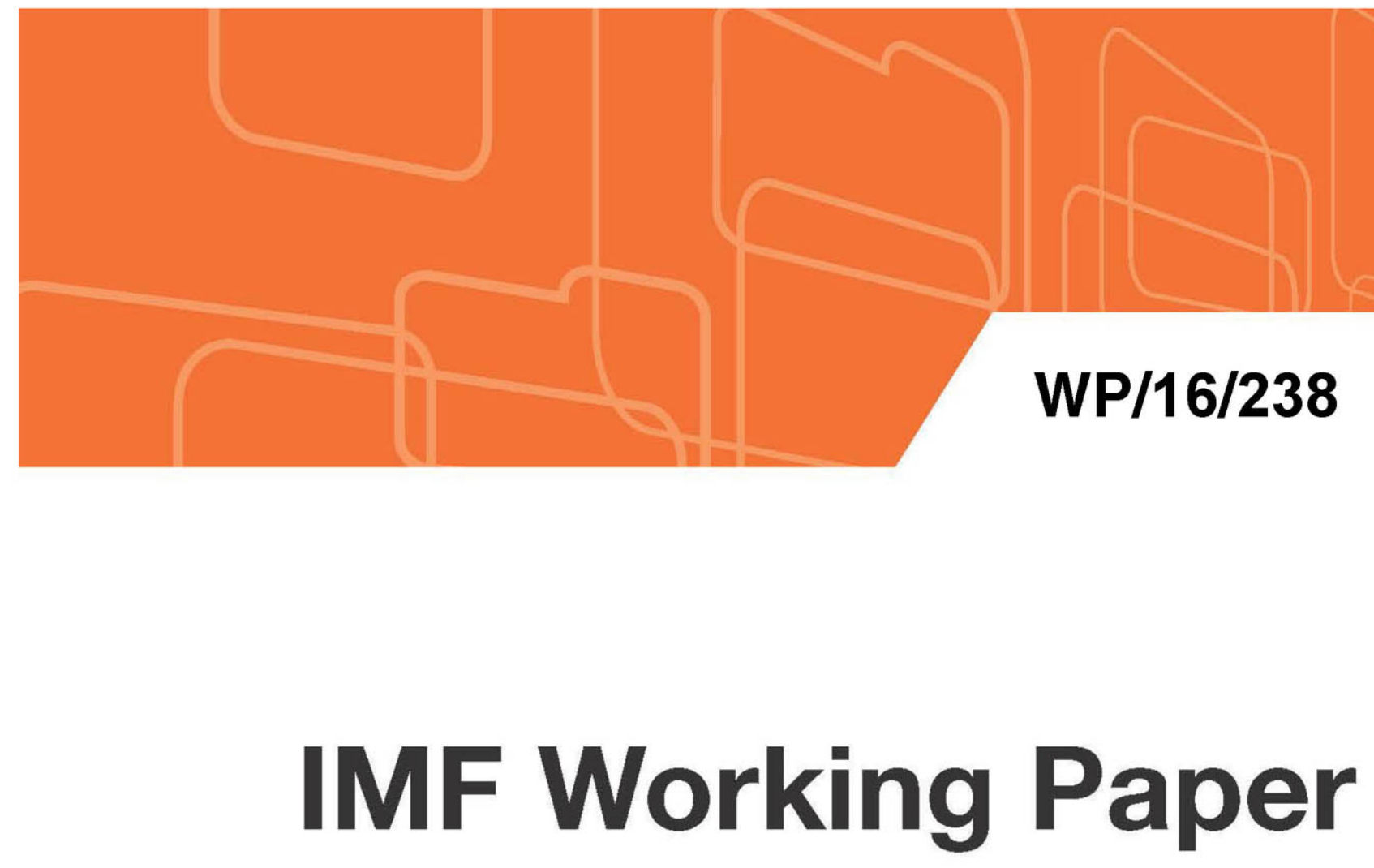

\title{
The Impact of Workforce Aging on European Productivity
}

by Shekhar Aiyar, Christian Ebeke and Xiaobo Shao

IMF Working Papers describe research in progress by the author(s) and are published to elicit comments and to encourage debate. The views expressed in IMF Working Papers are those of the author(s) and do not necessarily represent the views of the IMF, its Executive Board, or IMF management. 


\section{WP/16/238}

\section{IMF Working Paper}

\section{The Impact of Workforce Aging on European Productivity}

by Shekhar Aiyar, Christian Ebeke and Xiaobo Shao

IMF Working Papers describe research in progress by the author(s) and are published to elicit comments and to encourage debate. The views expressed in IMF Working Papers are those of the author(s) and do not necessarily represent the views of the IMF, its Executive Board, or IMF management.

I N T E R N A T I O N A L MON E T A R Y FUN D 


\title{
IMF Working Paper
}

European Department

\author{
The Impact of Workforce Aging on European Productivity ${ }^{1}$ \\ Prepared by Shekhar Aiyar, Christian Ebeke and Xiaobo Shao \\ Authorized for distribution by Shekhar Aiyar
}

December 2016

\begin{abstract}
IMF Working Papers describe research in progress by the author(s) and are published to elicit comments and to encourage debate. The views expressed in IMF Working Papers are those of the author(s) and do not necessarily represent the views of the IMF, its Executive Board, or IMF management.
\end{abstract}

\begin{abstract}
The age-distribution of Europe's workforce has shifted towards older workers over the past few decades, a process expected to accelerate in the years ahead.. This paper studies the effect of the aging of the workforce on labor productivity, identifies the main transmission channels, and examines what policies might mitigate the effects of aging. We find that workforce aging reduces growth in labor productivity, mainly through its negative effect on TFP growth. Projected workforce aging could reduce TFP growth by an average of 0.2 percentage points every year over the next two decades. A variety of policies could ameliorate this effect.
\end{abstract}

JEL Classification Numbers: E23, O30, O47.

Keywords: Workforce Aging; Productivity; Policies

Author's E-Mail Address: saiyar@imf.org; cebeke@imf.org; xshao@imf.org

1. We are indebted to Mahmood Pradhan, Ken Kang, Serkan Arslanalp, Hua Chai, Dominique Fayad, Rob Gregory, Robert Kerry, Manasa Patnam, Marcos Poplawski Ribeiro, Jacqueline Rothfels, Reza Yousefi and Niklas Westelius for useful comments and suggestions. The paper also benefited from the comments of seminar participants at the European Commission and IMF. 


\section{Contents}

ABSTRACT _ _ $\underline{2}$

I. WORKFORCE AGING __ $\underline{4}$

II. ESTIMATING THE EFFECT OF AGING ON PRODUCTIVITY ___ $\underline{8}$

A. Empirical design and baseline estimates ___ $\underline{8}$

B. Identification strategy __

C. Robustness checks —

III. QUANTIFYING THE PAST AND FUTURE EFFECTS OF AGING ON TFP GROWTH __ $\underline{13}$

IV. LIVING WITH AGING: THE ROLE OF POLICIES __

A. Empirical design ___

B. Results _—

V. CONCLUSION__

VI. REFERENCES __ $\underline{20}$ 


\section{WORKFORCE AGING}

As is well known, Europe's population is aging. Declining fertility rates combined with increased life expectancy have reduced the natural increase in population. Immigration has helped to offset this trend but only partially. The old age dependency ratio is high in a number of European countries, and expected to rise considerably (Figure 1).

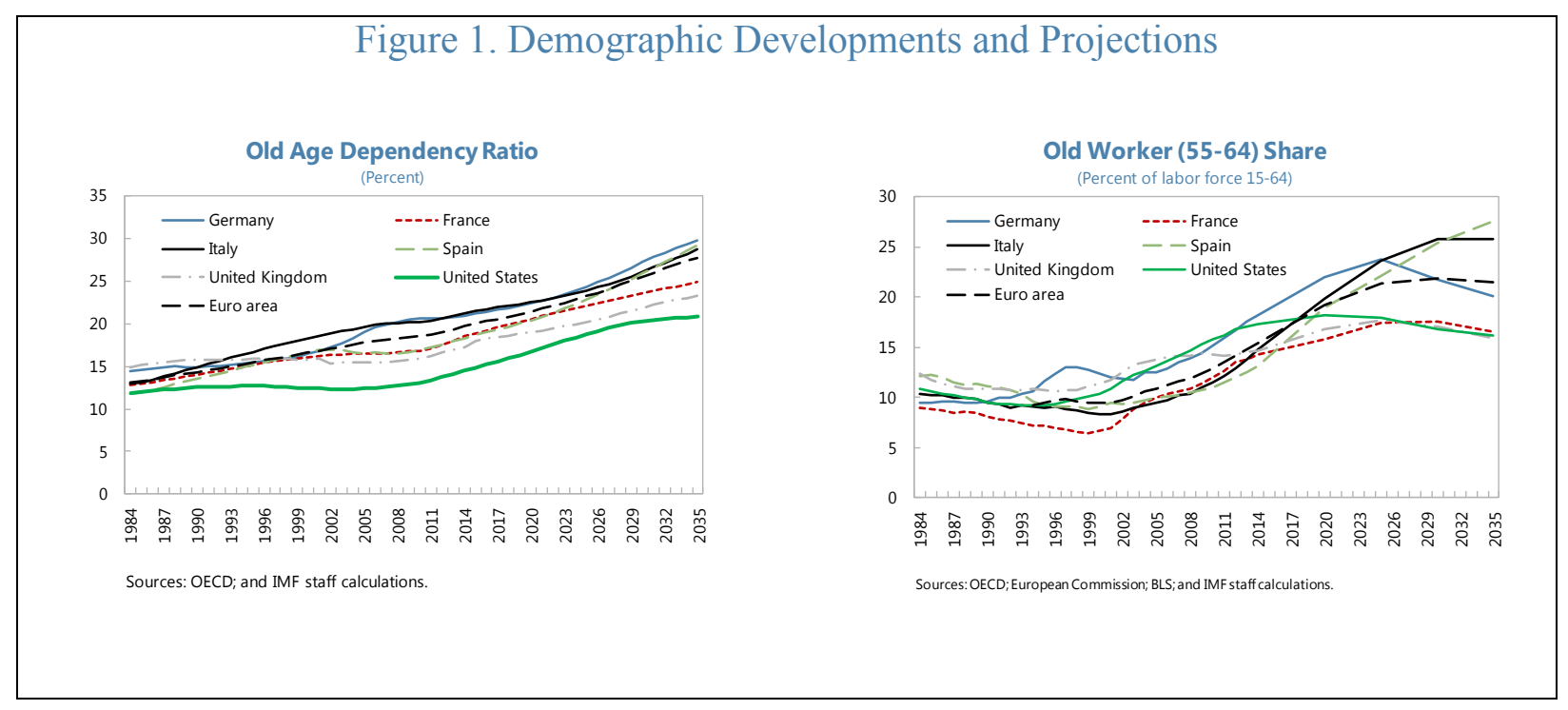

In addition to population aging, demographic projections point to a rapid aging of the European workforce. Not only will there be a sharp increase in the old-age dependency ratio, but also a shift in the composition of the workforce from relatively young to relatively old workers, a phenomenon that we will refer to as "workforce aging". In particular, the share of workers aged $55+$ in the labor force is expected to increase substantially over the next few decades, especially in countries such as Spain, Italy, Portugal, Greece and Ireland.

Aging exerts a macroeconomic impact in two conceptually different ways: through a higher dependency ratio (i.e. a higher proportion of retirees to workers), and through workforce aging. The first of these, the impact of a higher dependency ratio, has been well studied. Mechanically, fewer workers in a fixed population produce less output, so per capita GDP should fall with a higher dependency ratio. ${ }^{2}$ But there are several other channels. The life cycle theory suggests

\footnotetext{
${ }^{2}$ Several studies document a negative impact of a higher dependency ratio on per capita GDP growth in different parts of the world, e.g. Persson (2002) for the US; Bloom, Canning and Malaney (2000) for East Asia; Aiyar and
} Mody (2013) for India. 
that aggregate savings rates could decline as the elderly dissave after retirement. Public finances could be put under pressure in graying economies as the level of age-related spending increases. The erosion of fiscal buffers - coupled with more volatile participation rates for seniors - could lead to greater aggregate volatility (Jaimovich and Siu, 2009). Recent papers have also examined the role of aging on the structural transformation of economies, noting that the consumption pattern shifts towards goods that are more relevant for the elderly, such as energy, house-keeping, health and leisure services. The supply-side composition of the economy shifts in tandem, with the service sector growing relative to manufacturing (Siliverstovs et al., 2011).

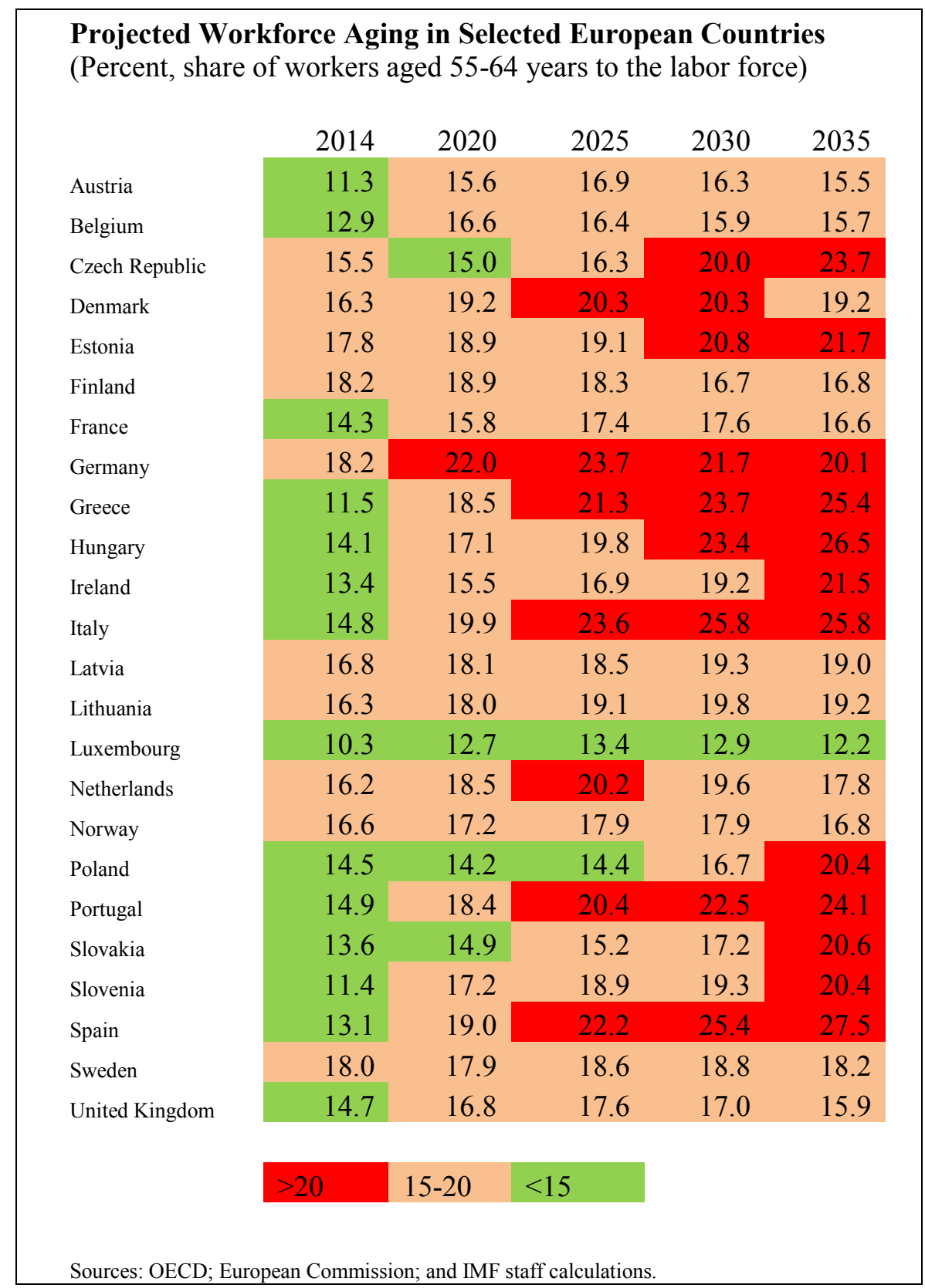


Workforce aging has direct implications for labor productivity. If different age cohorts differ in their productivity, then changes in the age distribution of the workforce will affect average output per worker. The literature stresses that a worker's productivity systematically varies over his or her working life, for reasons such as the accumulation of experience over time, depreciation of knowledge, and age-related trends in physical and mental capabilities. A more mature labor force will have higher average levels of work experience, with potentially positive effects on productivity (Disney, 1996). On the other hand, workforce skills also depend on the stock of knowledge acquired before entering the labor market, or in the early stages of individuals' careers. This stock of skills is likely to become increasingly dated as the average age of participants in the workforce rises, with negative effects on innovation and productivity (Dixon, 2003). Moreover, if job requirements change over time, older workers may find it more difficult to adapt (OECD, 1998). For example, some have argued that the increased penetration of information technologies might place older workers at a disadvantage (Dixon, 2003).

The combination of these factors typically leads to profiles exhibiting a strong increase in productivity until workers are in their 40s and a decline toward the end of their working life. Several scholars emphasize a drop-off in the productivity of senior workers related to lower levels of innovation, technology adoption and dissemination. For example, Feyrer (2008) shows that US innovators' median age is stable around 48 over the 1975-95 sample period whereas the median age of managers who adopt new ideas is lower at around 40. Aksoy et al (2015) show that demographic structure affects innovation, with older workers (in particular the 50-59 age group) having a strong negative impact on total number of patent applications. Jones (2010) finds that innovation is positively affected by young and middle-aged cohorts and negatively affected by older cohorts. Some recent papers, based on sector or firm-specific data have however found more mixed evidence. For example, Börsch-Supan and Weiss (2016) find that the productivity of workers in a large car manufacturer in Germany declines around age 60. These results might suggest that aggregate effects could be larger than sector or firm-level effects when externalities linked to workforce aging are taken into account (Feyrer, 2007).

The impact of aging on productivity may also differ across different occupations, in which case its aggregate impact would be sensitive to the industrial structure of the economy. Venn (2008) provides a taxonomy of economic sectors distinguished by their exposure to workforce aging risks: occupations and professions in which productivity increases (on average) with age, occupations that are age neutral, and occupations in which productivity declines with age. He argues that workers with basic jobs, especially jobs that require physical exertion such as factory 
workers or workers in the construction sector, are likely to become less productive as they age. Age-neutral occupations might include bank or commercial clerks and electronic engineers. Occupations in which productivity increases with age might include lawyers, professors, managers and medical doctors. If the impact of workforce aging differs between sectors, its aggregate impact would depend on the industrial structure of the economy. For the EU28 the data show a concentration of the workforce into occupations in which productivity decreases with age.

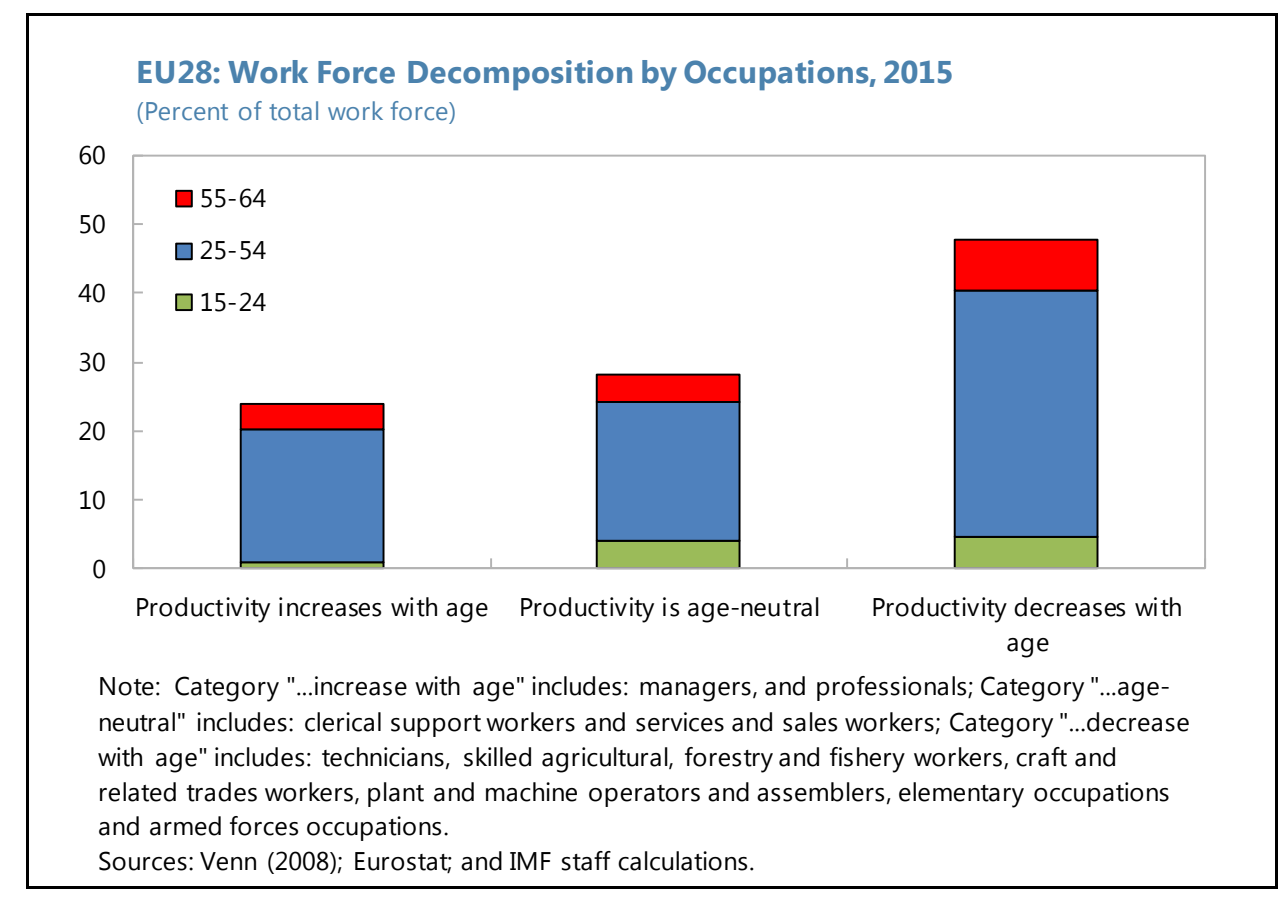

In this paper we examine the relationship between workforce aging and labor productivity in Europe. Drawing on the recent cross-country empirical literature (Feyrer, 2007; Cuaresma et al., 2016), we measure the effect of workforce aging (measured by the ratio of workers aged 55+ to the total workforce) on productivity. We find that an increase in this ratio is associated with an economically and statistically significant reduction in the growth rate of labor productivity. Further, we decompose the slowdown in labor productivity into factor accumulation and TFP growth, and find that most of the adverse effects of aging come from its negative impact on TFP growth. Our estimates show that the aging of the workforce in the euro area has lowered TFP growth by about 0.1 percentage points each year over the past two decades. The results are robust to various econometric specifications and different strategies to address potential endogeneity concerns. 
Our estimates suggest that workforce aging could significantly retard TFP growth over the medium to long term. On the basis of demographic projections from the OECD, the aging of the workforce in the euro area could lower TFP growth by about 0.2 percentage points each year between 2014 and 2035. This effect is very substantial given EC forecasts that most countries are expected to post average TFP growth rates of less than 1 percent every year over that horizon. To put it another way, absent the adverse impact of aging, TFP growth could be higher by about a quarter over the next two decades.

Finally, we examine if policy can mitigate the adverse effects of aging. Our analysis underscores the key role that can be played by specific policies to improve health outcomes, boost the productivity of workers through active labor market policy (ALMP) reforms, reduce the tax wedge to increase labor mobility and spur innovation through R\&D spending.

The rest of the paper is organized as follows. Section II lays out the framework for estimating the effect of workforce aging on productivity and proposes an identification strategy to assess causal effects. Section III undertakes backcasting and forecasting exercises for productivity growth building on the point estimates of the effects of workforce aging and time series of demographic variables. Section IV identifies policies and reforms which dampen the adverse effects of workforce aging on productivity. Section $\mathrm{V}$ concludes.

\section{Estimating the Effect of Aging on Productivity}

\section{A. Empirical design and baseline estimates}

We use standard panel techniques to estimate the effect of aging and its channels. Our baseline specifications build on work by Feyrer (2007) but expand his methodology to better account for heterogeneity across countries and endogeneity issues. ${ }^{3}$ The EC's 2015 Aging Report provides projections on participation rate and TFP growth for our simulation, so the sample comprises major EU28 countries over 1950 to 2014. The workforce and population data come from the OECD while the output per worker data are from the Penn World Table 9.0.

\footnotetext{
${ }^{3}$ Feyrer's (2007) analyses relate to up to 87 developed as well as to developing countries, and his data set spans the period from 1960 to 1990 . His major finding is an inversely $U$-shaped relationship between changes in the age structure of the labor force and the growth rate of TFP which peaks for workers aged 40-49.
} 
Our baseline model fits the growth in real output per worker on the share of workers aged 55+ years, the youth and the old dependency ratios, year and country fixed effects. Specifically, the model takes the following form:

$$
\Delta \log Y W_{i t}=\theta_{1} \mathrm{w}_{5} 5_{i t}+\theta_{2} \mathrm{YADR}_{i t}+\theta_{3} \mathrm{OADR}_{i t}+u_{i}+\eta_{t}+\epsilon_{i t}
$$

where YW denotes real output per worker, w55 is the share of the total workforce aged 55-64 years, and $Y A D R$ and $O A D R$ are the youth and old dependency ratios, respectively. We expect the coefficient $\theta_{1}$ to be negative and significant, implying that an increase in the share of old workers is negatively associated with the growth rate of output per worker, even after controlling for the dependency ratios. The country fixed effects should absorb country specific time-invariant factors affecting labor productivity, while the decadal time-specific effects are intended to account for common shocks affecting growth. ${ }^{4}$ Our benchmark regression does not identify the relative contributions of the various channels through which an aging workforce affects output per worker growth; only the sign and magnitude of the total effect, as in Jaimovich and Siu (2009).

We then attempt to identify the channels through which workforce aging affects real output per worker growth in line with the empirical literature on growth accounting (Wong, 2007; Feyrer, 2007). Assuming that the production technology follows a Cobb-Douglas function, output per worker is given by:

$y_{i t}=k_{i t}^{\alpha}\left(h_{i t} A_{i t}\right)^{1-\alpha}$, which can be re-written as $y_{i t}=\left(\frac{K}{Y}\right)_{i t}{ }^{\frac{\alpha}{1-\alpha}} A_{i t} h_{i t}$,

where $y$ is the real output per worker, $k$ is the real capital stock per worker, $h$ is human capital per worker, and A is the TFP. ${ }^{5}$ Taking logs of both sides gives:

\footnotetext{
${ }^{4}$ We control for time effects by decade to avoid the proliferation of parameters with annual time effects, given the long time dimension of the panel. We obtain broadly similar econometric results under several variants of this basic specification, such as including a lagged dependent variable, controlling for the entire age distribution of the workforce; and excluding the dependency ratios or the year effects.

${ }^{5}$ This decomposition assumes an augmented Cobb-Douglas production function with human capital, which has become standard in the literature (see for example Hall and Jones, 1999; and Aiyar and Feyrer, 2002). Alpha is the capital share, assumed to be around 0.3 (see Aiyar and Dalgaard, 2009 for a justification). The capital stock series,
}

(continued...) 
$\log \left(y_{i t}\right)=\frac{\alpha}{1-\alpha} \log \left(\frac{K}{Y}\right)_{i t}+\log \left(h_{i t}\right)+\log \left(A_{i t}\right)$

Following Wong (2007), we use this decomposition to estimate separately the effect of the variable of interest - here the workforce aging variable — on each of the right hand side variables in equation (2), i.e. factor accumulation (capital and human capital) and TFP growth rates. Wong (2007) shows that the coefficient on the workforce aging variable derived from each of these regressions will sum up to the effect of workforce aging on labor productivity growth estimated in equation (1).

Using ordinary least squares, we obtain two main econometric results. First, there is a significant negative impact of an increase in the share of the workers aged 55-64 on the real growth of output per worker. This is shown in the first column of Table 1. Second, the main channel through which an aging workforce reduces the growth rate of output per worker is lower TFP growth. Columns 2-5 decompose the impact into factors of production and TFP. Column 2 suggests that physical capital — one of the two sources of factor accumulation—does play a statistically significant role. But its economic significance is small compared to the role of TFP (shown in columns 4 and 5). ${ }^{6}$ This may suggest specialization patterns into capital-intensive technologies to complement the older and gradually less productive workers.

\section{B. Identification strategy}

The specification in equation (1) is potentially subject to endogeneity problems because the share of any particular age group in the labor force depends not only on the number of people in that age category, but also on the participation rate of that cohort. This may be influenced directly by the growth of output per worker; or both the participation rate and output per worker may be influenced by common (country-specific) shocks.

output, and human capital data are from Penn World Table 9.0. Human capital is an index defined in terms of average years of schooling, with the returns to primary, secondary and tertiary education based on Mincer equation estimates from around the world taken from Psacharopoulos (1994). TFP is computed as a residual from the log of real output per worker minus the capital intensity weighted by the factor share expression, and minus the log of human capital per worker.

${ }^{6}$ Two different variants of TFP are used for this exercise. In column 4 we use TFP backed-out as a residual from equation [2] above. In column 5 we use the Penn World Tables' own estimates of TFP. 
The direction of the endogeneity bias crucially depends on the extent to which the labor force participation rates of various age groups are sensitive to cyclical shocks. In particular, if the relative participation rate of the age group 55-64 increases in response to a positive productivity shock - that is, if the participation rate of the w55 group is more elastic with respect to productivity shocks than other age cohorts - this would tend to increase the share of the 55-64 age cohort in the total workforce. In turn, this implies that the coefficient $\theta_{1}$ will be biased upward. In other words, a naïve estimate of this coefficient is contaminated by the positive effect of productivity shocks on the relative participation rate of the group 55-64.

A possible test of this conjecture is to regress participation rates of different age groups on (lagged) aggregate productivity shocks. Following recent findings in the literature, we expect the participation rate of older and younger cohorts to exhibit substantial volatility. Jaimovich and Siu (2009) highlight the existence of a distinct U-shaped pattern in the volatility of hours by age groups. These age-specific differences in the business cycle responsiveness of labor market variables are found in our data as well. Table A1 and Table A2 in Appendix A show the results of the econometric regressions of within-country changes in labor force participation rates on lagged productivity growth. In Table A1, we show that changes in the labor force participation rate of older workers (55-64) is much more responsive to productivity shocks than any other group. When an alternative measure of productivity growth is used (output per hour worked) in Table A2, the results are qualitatively similar but with the additional finding that the participation of younger cohorts (15-19 and 20-29) is also responsive to business cycle developments. These results confirm our prior that ignoring the existence of a reverse and positive causality running from productivity growth to the relative participation rate of 55-64 group substantially bias the estimate of $\theta_{1}$ upward.

To address potential endogeneity bias, we first instrument each country's share of the workforce aged 55 to 64 by the population share of those aged 45-54 ten years previously. To address the possibility that dependency ratios (included in the models as control variables) can also be endogenous (for example if an immigration shock simultaneously shifts the population distribution and affects the growth rate of output), we instrument the youth and old dependency ratios with the share of population under the age of 4 and the population share of those aged 55 to 59 years ten years ago. The results from the first-stage regressions (Table A3 in the Appendix) show that the instruments are strongly correlated with the endogenous demographic variables. The first-stage $F$-statistics comfortably exceed the Staiger and Stock (1997) rule of thumb of 10 , indicating that weak instrument pathologies are unlikely to be a concern in these specifications. 
However, even the lagged population proportions used as instruments may be endogenous if the shocks that affected the lagged population proportions ten years ago continue to influence current output per worker or TFP growth today. To address this critique, we instrument the workforce aging variable and the dependency ratio with lagged birth rates 40, 30, 20, and 10 years ago, similar to Jaimovich and Siu (2009). Excluding migration and mortality, an age group's share of the 15-64-year-old population is determined by the distribution of births 15 to 64 years prior. To the extent that fertility decisions taken at least fifteen years ago are exogenous to current productivity growth, using lagged birth as instruments allows us to obtain unbiased estimates of the causal impact of the labor force composition of old workers. The drawback of this approach is a significant reduction in the number of observations, as we instrument the age composition of the workforce using very long lags. ${ }^{7}$ However, this identification strategy is likely to provide cleaner estimates of a causal impact. Again, the $F$-statistic of the instrumentation equations show a robust and strong correlation between the birth rate instruments and the endogenous demographic variables (Table A4).

As expected from the discussion of the direction of the endogeneity bias, the effect is larger (more negative) and more precisely estimated using instrumental variables (Table 2). ${ }^{8}$ An increase in the share of workers aged 55-64 by 1 percentage point leads to a decline in the growth of output per worker of between 0.25 and 0.7 percentage points. ${ }^{9}$ In terms of transmission channels, it is robustly estimated that the bulk of the negative effect of workforce aging on labor productivity comes from its negative impact on TFP growth. This result is

\footnotetext{
${ }^{7}$ In this specification, given the reduced number of observations, we combine the youth and old dependency ratios into the overall age dependency ratio to limit the number of variables that require instrumentation.

${ }^{8}$ Because the use of long lags of birth rates (40 years ago, for example) reduces the sample considerably and leads in particular to dropping older observations, our second instrumentation strategy could lead to different point estimates in part due to the changing sample. In order to check that the effect of aging in this set up is not driven by the change in sample, we also re-ran the previous instrumentation strategy using 10-year lagged population proportions as instruments on the reduced sample. The estimates are unaffected, supporting the view that the second instrumentation strategy gives stronger results because it deals with endogeneity better, not because the sample is altered.

${ }^{9}$ The first-stage regressions are consistent with our priors regarding the signs and the strength of the instruments. Diagnostic statistics suggest that the instruments are strong (the F-statistic and Shea $\mathrm{R}^{2}$ comfortably exceed conventional statistical thresholds).
} 
broadly similar to Feyrer (2007) and Werding (2008), who also found a dominant role for the TFP channel in a broad sample of advanced and developing economies in the pre-2000 period.

\section{Robustness checks}

The empirical specification employed in the previous section is robust to several modifications. Controlling for the numbers of hours worked does not modify the results. In the previous specification, labor input is measured in terms of the number of workers and does not account for differences in the number of hours worked, which could be affected both by cross-country heterogeneity and by aging. We therefore follow Feyrer (2007) in normalizing both real output and TFP by hours worked, using OECD data. The regression results robustly point to a negative and statistically significant effect of the share of workers aged 55+ on both output per hour and modified TFP growth (defined as the difference between the log of TFP and the log of hours worked). These are denoted, respectively, as D.lnYH and D.lnAH (Table 3).

Controlling for the entire age distribution does not modify the results. We extend the analysis to include a more detailed look at the effect of the workforce age composition. We alter our empirical specification so that the regressor, w55, is replaced by a vector of labor force shares: the shares of the 30-39, 40-49, 50-54, and 55-64, age groups. We exclude the 15-29 age group because all age shares together sum to one. This means that the coefficient on any particular age group represents the impact from a shift of the workforce share out of the 15-29 group, into that age group. As shown in Table 4, the impact of the age group 55-64 remains negative and statistically significant. ${ }^{10}$

\section{QUANTIFYING THE PAST AND FUTURE EFFECTS OF AGING ON TFP GROWTH}

Using the point estimates obtained in Table 2 column 4 (bottom regression), and drawing on evolution of the share of workers aged 55-64 in the total workforce, we can decompose the contribution of the aging workforce to TFP growth in each euro area country from 1984 to

\footnotetext{
${ }^{10}$ Using instrumental variables as in Table 2 is challenging in these specifications because instrumenting for multiple age cohorts entails the loss of too many degrees of freedom.
}

(continued...) 
2007. ${ }^{11}$ Figure 2 shows that on average workforce aging has reduced TFP by about 0.1 percentage points per annum to date. However, this is not uniformly the case. In some countries, such as Latvia, Lithuania, Finland, Netherlands and Germany, the loss was greater, with about 0.2 percentage points of TFP growth per annum shaved-off during this period, due to increases in the share of workers aged 55-64.

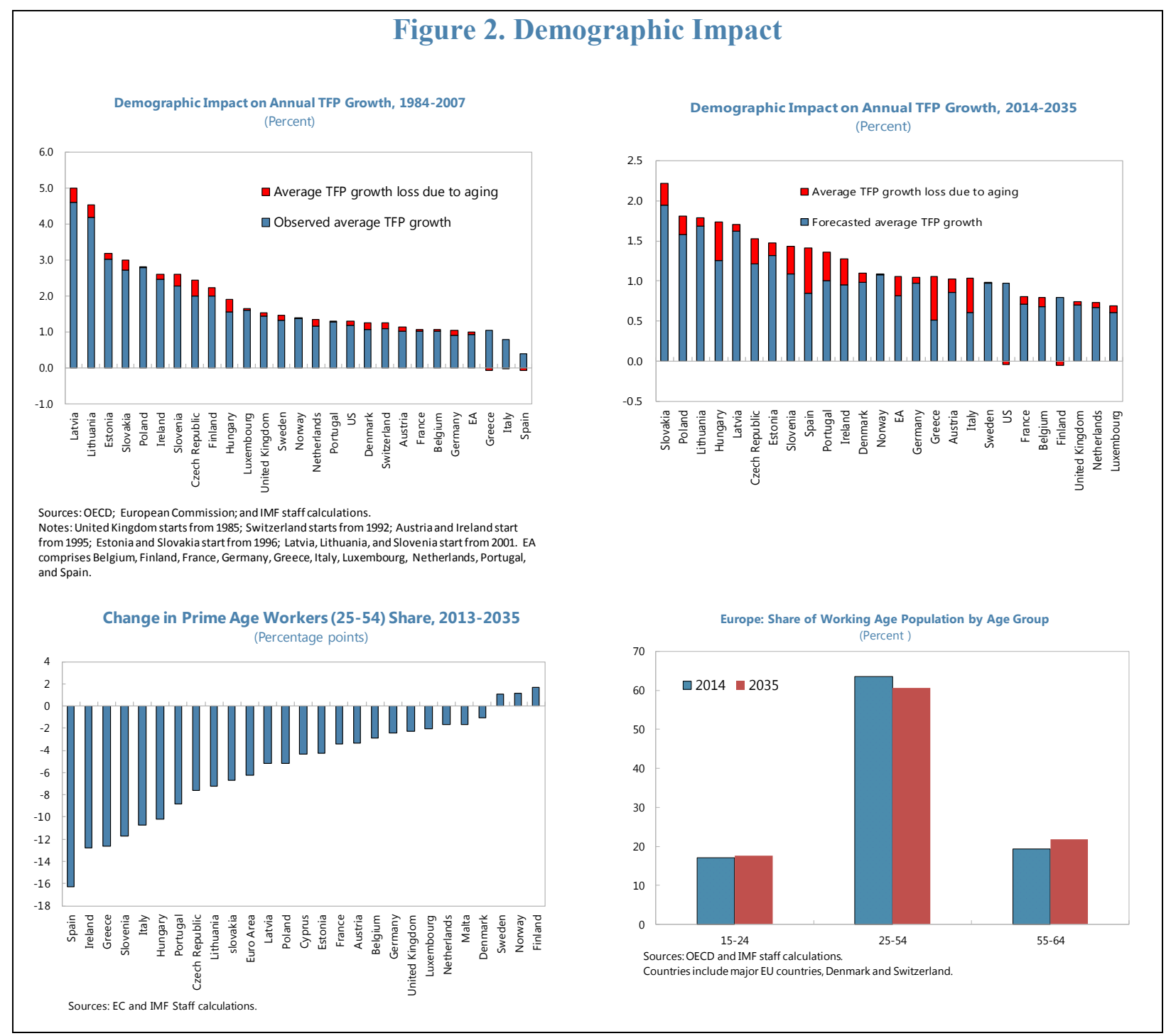

\footnotetext{
${ }^{11}$ The results obtained using the lagged births as instrumental variables are our preferred specifications given the stronger orthogonality of these instruments vis-à-vis the dependent variables. It is very unlikely that the birth rate 40 years ago could affect productivity performance today through any channel other than the aging variables.
} 
The future effects of workforce aging on TFP growth will be more severe. Using the OECD forecast of working age population by age groups and the EC's 2015 Aging Report for projections of labor force participation rates, we construct projections of the share of the workforce aged between 55 and 64 years old in each country from 2014 until 2035. We then use our econometric estimates of the effect of workforce aging to derive projections of the contribution of aging to TFP growth in the long-run. Our calculations point to a more severe effect of demographic pressures on TFP growth in the years to come, consistent with the rapid worsening of the age profile of the workforce expected in Europe. ${ }^{12}$ On average workforce aging will shave off about 0.2 percentage points of TFP growth every year until 2035. and the scale of this effect is substantial if one takes into account that the projected average annual TFP growth in European is only about 1 percentage point per annum. In other words, in the absence of workforce aging, the TFP growth through 2035 could be about one quarter higher than the current forecast. The countries expected to be worst affected by workforce aging are Greece, Spain, Portugal, Italy, Hungary, Slovenia, Slovakia and Ireland, where the average increase in the share of old workers in total workforce is about 10 percentage points between 2020 and 2035 , and the average loss ratio, the ratio of projected TFP growth loss due to workforce aging over the projected TFP growth, is about 0.6 . Many of these countries are also currently facing a high debt burden (Figure 3).

\footnotetext{
${ }^{12}$ As shown in the Figure 2, demographic projections from the European Commission show a significant increase in the share of the workforce aged 55-64 between 2014 and 2035, the only cohort to record a positive increase of this magnitude.
} 


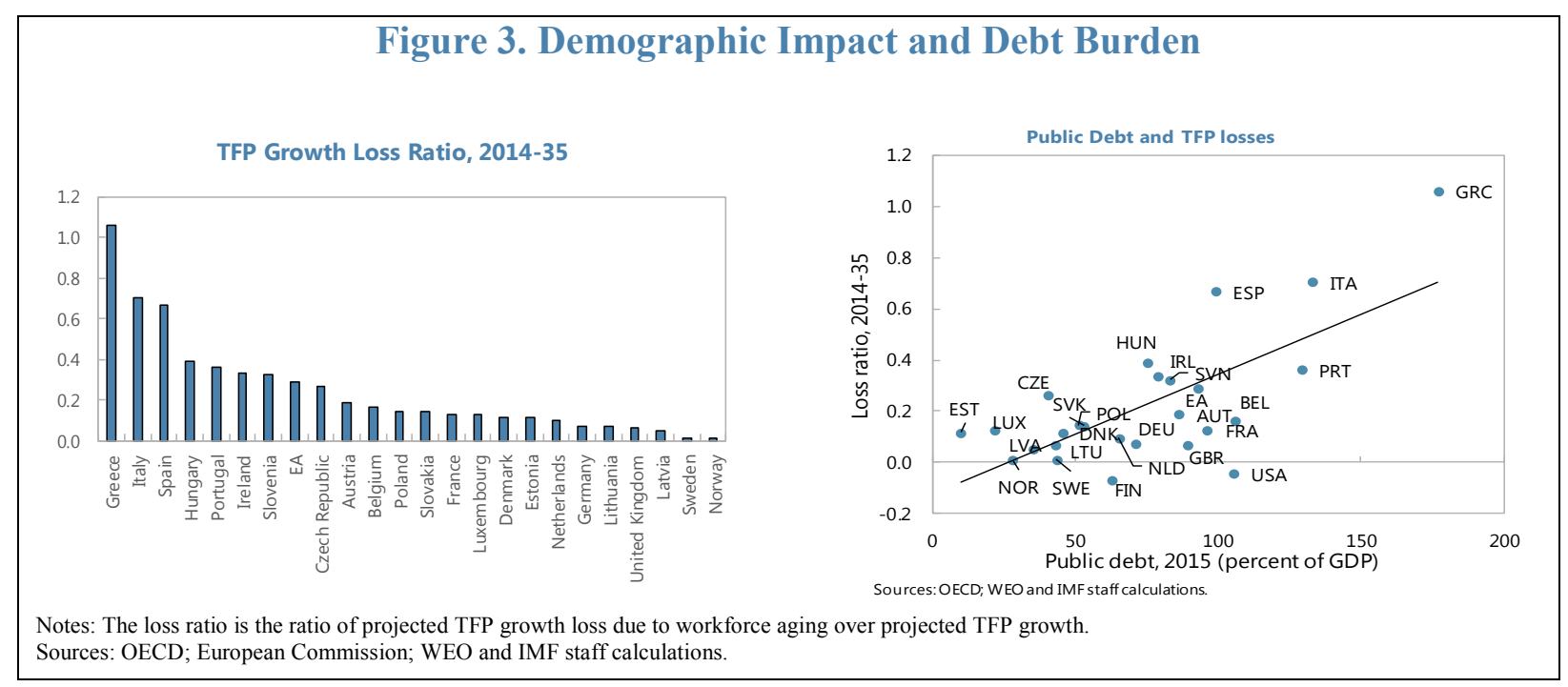

\section{Living With Aging: The Role of Policies}

In this section we attempt to identify policies that would reduce the marginal negative effect of workforce aging on TFP growth. These could potentially include several reforms aimed at increasing labor productivity generally — such as innovations in health or training to improve human capital, the encouragement of greater innovation and technology adoption, and the facilitation of productive labor reallocations - provided that the reforms disproportionately enhance the productivity of the 55 plus cohort of workers.

\section{A. Empirical design}

Our baseline specification is altered to allow for an interaction of workforce aging with a selected conditioning variable:

$\Delta \log A_{i t}=\left(\theta_{4}+\theta_{5} P_{i t-1}\right) \cdot \mathrm{w} 55_{i t}+\beta P_{i t-1}+\theta_{6} \mathrm{YADR}_{i t}+\theta_{7} \mathrm{OADR}_{i t}+u_{i}+\eta_{t}+v_{i t}$

where the variable $P$ denotes the conditional factor mediating the relationship between TFP growth and the share of old workers (w55). The policy variables enter the model with a lag to reduce endogeneity risks. The policy variable $P$ will have an ameliorating impact if $\theta_{4}<0$ and $\theta_{5}>0$. This implies that the marginal (and negative) effect of aging on TFP growth is reduced for higher values of the conditional factor $P$. We test for various conditional factors:

- Health conditions and human capital accumulation: Aging is associated with a rise in the incidence of ill health and disability within the workforce (Dixon, 2003). The negative impact of an aging workforce on growth could be mitigated by better health 
conditions and upgraded human capital. Our health care indicator is the availability of doctors measured by the physician density in total population. ${ }^{13}$ While doctor availability is an important and widely used "input" indicator for a society's health levels at all age categories, it is likely to be of particular relevance for older people, who are disproportionately likely to be at health risk. We also test for the effect of active labor market policies (ALMPs) focusing on the training or re-training of the workforce (reform dummy taking the value of one when the change in public spending per unemployed on ALMP on training is greater than one standard deviation of the sample deviation). ${ }^{14}$ As with health, while ALMPs could in principle benefit all age cohorts, they are likely to be disproportionately beneficial to senior workers with more dated skills.

- Labor market flexibility: Workforce aging is expected to be associated with reduced voluntary mobility between jobs, as younger workers tend to change jobs and employers relatively frequently, while older workers tend to have more stable relationships with their employers. A decline in voluntary job mobility could have negative consequences as the labor market as a whole might become less flexible (Dixon, 2003). In turn, this is likely to reduce productivity, since adjusting to changes in technology and changes in product markets could require the movement of workers across firms and geographical regions. We use reforms to the employment protection framework to proxy for labor market flexibility, creating a dummy variable taking the value 1 when the OECD indicator of employment protection of regular contracts declines by at least 1 standard deviation of the sample. ${ }^{15}$

- Tax wedge. High rates of tax on marginal employment, coupled with out-of-work benefits can create disincentives to working for any age group. However, the effect may

\footnotetext{
${ }^{13}$ It should be noted that this measure suffers from some limitations. Even if physician density is high, the quality of the health insurance system could still limit access to health care for some income groups. The problem is likely to increase with population aging that threatens the sustainability of public health care systems, as well pension systems viability affecting elder households' income and their capacity to privately finance medical care.

${ }^{14}$ Data on ALMP spending are from Eurostat.

${ }^{15}$ Defining structural reform occurrences by dummies variables indicating significant changes in underlying structural indices follows the empirical literature on the macroeconomic effects of structural reforms (Bordon et al., 2016).
} 
be disproportionately important for seniors because they have larger savings to fall back on than other age cohorts in case of unemployment, and may also have a greater preference for leisure based on their stage of life. The incentive to delay retirement could be eroded by high labor taxation. We define a dummy for the reform of the tax wedge taking the value of 1 when the OECD indicator of the tax wedge declines by at least 1 standard deviation. ${ }^{16}$

- Innovation. Technological innovation and adoption is an important source of productivity improvements for the labor force as a whole. To the extent that it differentially benefits senior workers, it could also mitigate the negative impact of aging. In principle, one could think of innovations that favor younger workers (e.g. new computer software that enhances the efficiency of those who are capable of easily "switching") and innovations that favor older workers (e.g. mechanical devices that reduce the physical labor associated with certain manufacturing processes). In practice, whether technological innovations on balance favor older workers more than younger workers is an empirical matter. We test whether the effect of aging on TFP growth is dampened by higher spending on $\mathrm{R} \& \mathrm{D}$, differentiating between public and private spending on R\&D as a percentage of GDP.

\section{B. Results}

We find that policy reforms to improve human capital, labor participation, and innovation do tend to mitigate the adverse impact of aging on TFP growth. The estimates in Table 5 show a robust dampening effect of policy variables. Columns 1 and 2 suggest that providing greater access to health services and active labor market policies focusing on the training of the labor force dampen the TFP growth-reducing effects of an aging workforce. While the results indicate that fiscal reforms lowering the tax wedge could be an important counterbalance to demographic pressures (column 3), the effect of labor market reforms granting more flexibility (less protection of regular workers) has the expected sign but is not statistically significant (column 4). Column 5 shows that the government contribution to R\&D spending is robustly associated with a reduced effect of aging on TFP growth, whereas the effect of private sector R\&D in the euro area remains statistically unclear (column 6). This may be due to the still very low levels of private sector $R \& D$ in several sample countries.

\footnotetext{
${ }^{16}$ Examining the effect of reforms of the tax wedge is useful in its own right given the interest in this variable in the ongoing benchmarking exercise by the Eurogroup.
} 
A summary of these results is represented graphically in the chart below. The bars show the point estimate of the effect of workforce aging (a percentage point increase in the share of workers aged 55-64) on TFP growth conditional on the value of some policies. The results highlight the crucial role played by labor market reforms such as increases in active labor market policies on training or increase in the availability of medical inputs.

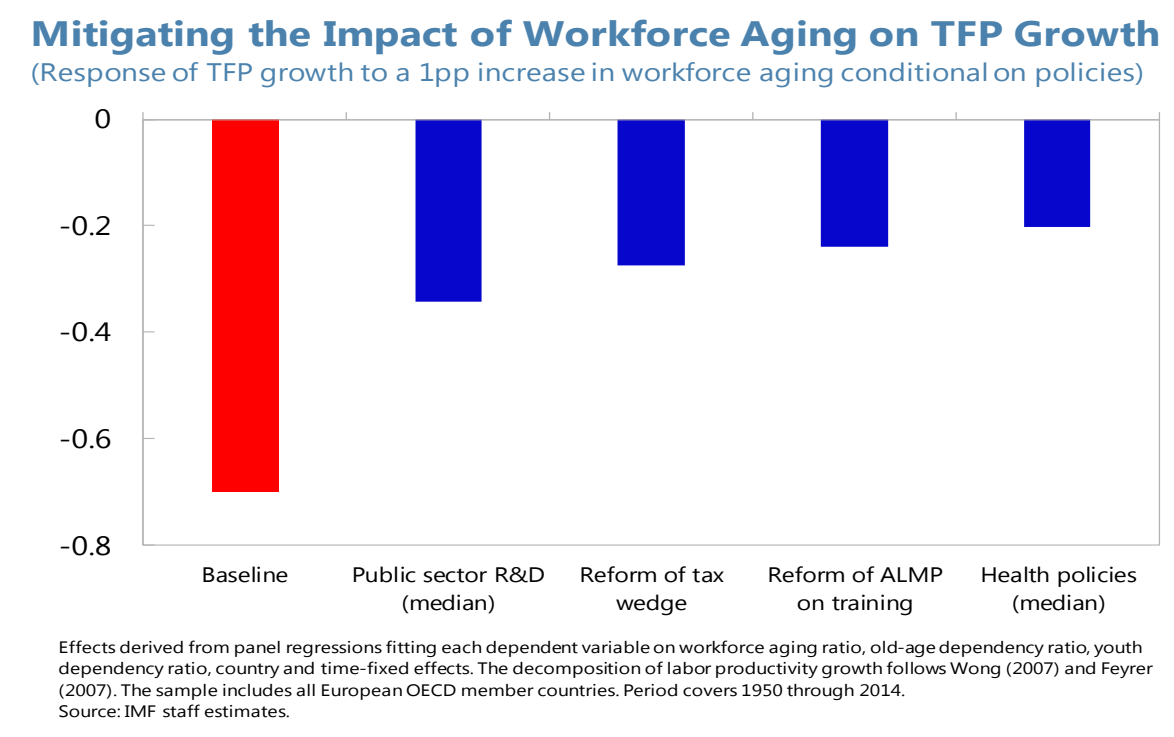

\section{Conclusion}

Workforce aging is likely to be a significant drag on European productivity growth over the next few decades. We estimate that a 1 percentage point increase in the 55-64 age cohort of the labor force is associated with a reduction in total factor productivity of about $4 / 5$ of a percentage point. Extrapolating this result forward, projected aging could reduce TFP growth by an average of 0.2 percentage points per annum over the next twenty years. The largest negative impact will occur in those countries — such as Spain, Italy, Portugal, Greece and Ireland — where rapid workforce aging is expected, and which also face high debt burdens.

Our analysis also suggests that good policies can ameliorate the negative productivity impact of an aging workforce. A variety of policies can help, such as broadening access to health services, improving workforce training, increasing labor market flexibility by lowering the tax wedge, and promoting innovation via higher $R \& D$ to adapt to a changing global environment. Of course many of these policies are desirable in their own right, and may increase productivity growth through multiple channels, but our analysis shows that they are likely to have a disproportionately large impact in rapidly aging societies such as Europe. 


\section{REFERENCES}

Aiyar, Shekhar and Dalgaard, Carl-Johan, 2009. Accounting for productivity: Is it OK to assume that the world is Cobb-Douglas?, Journal of Macroeconomics, Elsevier, vol. 31(2), pages 290 303, June.

Aiyar, Shekhar and Mody, Ashoka, 2013. The Demographic Dividend: Evidence from the Indian States, India Policy Forum, National Council of Applied Economic Research, vol. 9(1), pages 105-148.

Aiyar, Shekhar, and Feyrer, James, 2002. A Contribution to the Empirics of Total Factor Productivity, Dartmouth College working paper.

Aksoy, Yunus, Basso, \& Henrique, Grasl, Tobias, and Smith, Ron. 2015. Demographic Structure and Macroeconomic Trends, Birkbeck Working Papers in Economics and Finance 1501, Birkbeck, Department of Economics, Mathematics \& Statistics.

Bloom, D., Canning, D., and P. Malaney, P., 2000. Population dynamics and economic growth in Asia. Population and Development Review, 26 (Supplement), pages 257-90.

Bordon, Anna Rose, Ebeke, Christian, and Shirono, Kazuko, 2016. When Do Structural Reforms Work? On the Role of the Business Cycle and Macroeconomic Policies, IMF Working Papers 16/62, International Monetary Fund.

Börsch-Supan, Axel, and Weiss, Matthias, 2016. Productivity and age: Evidence from work teams at the assembly line, The Journal of the Economics of Ageing, vol.7, pages 30-42.

Clements, Benedict, Dybczak, Kamil, Gaspar, Vitor, Gupta, Sanjeev, and Soto, Mauricio, 2015. The Fiscal Consequences of Shrinking Populations, IMF Staff Discussion Notes 15/21, International Monetary Fund.

Cuaresma, Crespo, Loichinger, Elke, and Gallina, Vincelette, 2016. Aging and income convergence in Europe: A survey of the literature and insights from a demographic projection exercise, Economic Systems, Elsevier, vol. 40(1), pages 4-17.

Disney, Richard, 1996. Can we afford to grow older? A Perspective on the economics of aging, MIT Press, Cambridge: Mass. 
Dixon, Silvia, 2003. Implications of population ageing for the labour market. Labour Market Trends, February.

Feyrer, James, 2007. Demographics and Productivity, The Review of Economics and Statistics, MIT Press, vol. 89(1), pages 100-109.

Feyrer, James, 2008. Aggregate evidence on the link between age structure and productivity, Population and Development Review, pages 78-99.

Göbel, Christian and Zwick, Thomas, 2012. Age and Productivity: Sector Differences, De Economist, Springer, vol. 160(1), pages 35-57, March.

Hall, Robert, and Jones, Charles I., 1991. Why Do Some Countries Produce So Much More Output per Worker Than Others? Quarterly Journal of Economics 114:1, pages 83-116.

Jaimovich, Nir, and Siu, Henry, 2009. The Young, the Old, and the Restless: Demographics and Business Cycle Volatility, American Economic Review, American Economic Association, vol. 99(3), pages 804-26, June.

Jones, Benjamin, 2010. Age and Great Invention, The Review of Economics and Statistics, MIT Press, vol. 92(1), pages 1-14, February.

Persson, Joakim, 2002. Demographics, Human Capital, and Economic Growth: A Study of US States 1930-2000, FIEF working paper, February.

Psacharopoulos, George, 1994. Returns to investment in education: A global update, World Development, Elsevier, vol. 22(9), pages 1325-1343, September.

Siliverstovs, Boriss, Kholodilin, Konstantin, Thiessen, Ulrich, 2011. Does aging influence structural change? Evidence from panel data, Economic Systems, Elsevier, vol. 35(2), pages 244-260, June.

Staiger, Douglas, and James H. Stock, 1997. Instrumental Variables Regression with Weak Instruments, Econometrica, 65, 557-586.

Veen, S., 2008. Demographischer Wandel, alternde Belegschaften und Betriebsproduktivität. Munich: Rainer Hampp Verlag.

Werding, Martin, 2008. Ageing and Productivity Growth: Are there Macro-level Cohort Effects of Human Capital?, CESifo Working Paper Series 2207, CESifo Group Munich. 
Wong, Wei-Kang, 2007. Economic Growth: A Channel Decomposition Exercise, The B.E. Journal of Macroeconomics: vol. 7: Iss. 1 (Topics), Article 4. 


\begin{tabular}{|c|c|c|c|c|c|}
\hline $\begin{array}{l}\text { Dependent } \\
\text { variables }\end{array}$ & $\begin{array}{c}(1) \\
\text { D. } \operatorname{lnYW} \\
\end{array}$ & $\begin{array}{c}(2) \\
\text { D. } \operatorname{lnKY} \\
\end{array}$ & $\begin{array}{c}(3) \\
\text { D. } \ln H C \\
\end{array}$ & $\begin{array}{c}(4) \\
\text { D. } \ln A \\
\end{array}$ & $\begin{array}{c}5) \\
\text { D. } \ln \mathrm{A}^{\mathrm{PWT}} \\
\end{array}$ \\
\hline Workforce share aged 55-64 & $\begin{array}{c}-0.165^{* *} \\
(-2.409)\end{array}$ & $\begin{array}{c}0.0562 * * * \\
(2.237)\end{array}$ & $\begin{array}{l}0.00480 \\
(0.829)\end{array}$ & $\begin{array}{l}-0.228^{* * *} \\
(-2.491)\end{array}$ & $\begin{array}{c}-0.149 * * * * \\
(-3.023)\end{array}$ \\
\hline Old age dependency ratio & $\begin{array}{l}0.0287 \\
(0.203)\end{array}$ & $\begin{array}{l}-0.0546 \\
(-1.066)\end{array}$ & $\begin{array}{c}-0.0602 * * * \\
(-5.095)\end{array}$ & $\begin{array}{c}0.161 \\
(0.854)\end{array}$ & $\begin{array}{l}0.0313 \\
(0.310)\end{array}$ \\
\hline Youth dependency ratio & $\begin{array}{l}-0.0245 \\
(-0.250)\end{array}$ & $\begin{array}{l}0.0159 \\
(0.461)\end{array}$ & $\begin{array}{l}0.00854 \\
(1.071)\end{array}$ & $\begin{array}{l}-0.0405 \\
(-0.311)\end{array}$ & $\begin{array}{c}0.00442 \\
(0.0649)\end{array}$ \\
\hline Intercept & $\begin{array}{l}0.0293 \\
(0.842)\end{array}$ & $\begin{array}{c}0.00209 \\
(0.169)\end{array}$ & $\begin{array}{c}0.0132 * * * \\
(4.632)\end{array}$ & $\begin{array}{l}0.00985 \\
(0.213)\end{array}$ & $\begin{array}{l}0.0148 \\
(0.606)\end{array}$ \\
\hline County fixed effects & Yes & Yes & Yes & Yes & Yes \\
\hline Year fixed effects & Yes & Yes & Yes & Yes & Yes \\
\hline Observations & 679 & 700 & 700 & 679 & 700 \\
\hline Number of countries & 22 & 22 & 22 & 22 & 22 \\
\hline
\end{tabular}

$\operatorname{lnKY}$ is adjusted with $\alpha /(1-\alpha)$

t-statistics in parentheses

$* * * \mathrm{p}<0.01, * * \mathrm{p}<0.05, * \mathrm{p}<0.1$ 


\begin{tabular}{|c|c|c|c|c|c|}
\hline $\begin{array}{l}\text { Dependent } \\
\text { variables }\end{array}$ & $\begin{array}{c}(1) \\
\text { D.lnYW }\end{array}$ & $\begin{array}{c}(2) \\
\text { D. } \ln K Y \\
\end{array}$ & $\begin{array}{c}(3) \\
\text { D. } \ln \mathrm{HC} \\
\end{array}$ & $\begin{array}{c}(4) \\
\text { D. } \ln \mathrm{A}\end{array}$ & $\begin{array}{c}(5) \\
\text { D. } \ln A^{\text {PWT }} \\
\end{array}$ \\
\hline Workforce share aged 55-64 & $\begin{array}{l}-0.250 * * \\
(-2.502)\end{array}$ & $\begin{array}{l}0.0989 * * * \\
(2.785)\end{array}$ & $\begin{array}{c}0.00816 \\
(0.401)\end{array}$ & $\begin{array}{l}-0.363 * * \\
(-2.535)\end{array}$ & $\begin{array}{c}-0.235 * * * \\
(-2.923)\end{array}$ \\
\hline Old age dependency ratio & $\begin{array}{l}-0.207 \\
(-0.725)\end{array}$ & $\begin{array}{l}0.138 \\
(1.455)\end{array}$ & $\begin{array}{l}-0.0150 \\
(-0.458)\end{array}$ & $\begin{array}{l}-0.306 \\
(-0.802)\end{array}$ & $\begin{array}{l}-0.300 \\
(-1.283)\end{array}$ \\
\hline Youth dependency ratio & $\begin{array}{l}-0.0112 \\
(-0.0616)\end{array}$ & $\begin{array}{l}0.0461 \\
(0.654)\end{array}$ & $\begin{array}{c}0.0509^{*} \\
(1.887)\end{array}$ & $\begin{array}{l}-0.0932 \\
(-0.362)\end{array}$ & $\begin{array}{l}-0.0764 \\
(-0.511)\end{array}$ \\
\hline External instruments & $\begin{array}{c}\text { 10-year lagged } \\
\text { population } \\
\text { proportions }\end{array}$ & $\begin{array}{l}\text { 10-year lagged } \\
\text { population } \\
\text { proportions }\end{array}$ & $\begin{array}{l}\text { 10-year lagged } \\
\text { population } \\
\text { proportions }\end{array}$ & $\begin{array}{l}\text { 10-year lagged } \\
\text { population } \\
\text { proportions }\end{array}$ & $\begin{array}{l}\text { 10-year lagged } \\
\text { population } \\
\text { proportions }\end{array}$ \\
\hline Country fixed effects & Yes & Yes & Yes & Yes & Yes \\
\hline Year fixed effects & Yes & Yes & Yes & Yes & Yes \\
\hline Observations & 679 & 700 & 700 & 679 & 700 \\
\hline Number of countries & 22 & 22 & 22 & 22 & 22 \\
\hline Workforce share aged 55-64 & $\begin{array}{c}-0.700 * * * \\
(-4.625)\end{array}$ & $\begin{array}{c}0.217 * * * \\
(3.691)\end{array}$ & $\begin{array}{c}-0.0947 * * * \\
(-5.212)\end{array}$ & $\begin{array}{c}-0.823 * * * \\
(-4.003)\end{array}$ & $\begin{array}{c}-0.453 * * * \\
(-4.353)\end{array}$ \\
\hline Dependency ratio (combined) & $\begin{array}{l}-0.0163 \\
(-0.0662)\end{array}$ & $\begin{array}{l}-0.0824 \\
(-0.864)\end{array}$ & $\begin{array}{c}0.0849 * * * \\
(2.876)\end{array}$ & $\begin{array}{l}-0.0187 \\
(-0.0561)\end{array}$ & $\begin{array}{l}0.326^{*} \\
(1.931)\end{array}$ \\
\hline External instruments & $\begin{array}{l}\text { Births } 10,20,30, \\
\text { and } 40 \text { years ago }\end{array}$ & $\begin{array}{l}\text { Births } 10,20,30, \\
\text { and } 40 \text { years ago }\end{array}$ & $\begin{array}{l}\text { Births } 10,20,30, \\
\text { and } 40 \text { years ago }\end{array}$ & $\begin{array}{l}\text { Births } 10,20,30, \\
\text { and } 40 \text { years ago }\end{array}$ & $\begin{array}{l}\text { Births } 10,20,30, \\
\text { and } 40 \text { years ago }\end{array}$ \\
\hline Country fixed effects & Yes & Yes & Yes & Yes & Yes \\
\hline Year fixed effects & Yes & Yes & Yes & Yes & Yes \\
\hline Observations & 391 & 391 & 391 & 391 & 391 \\
\hline Number of countries & 21 & 21 & 21 & 21 & 21 \\
\hline
\end{tabular}

$\operatorname{lnKY}$ is adjusted with $\alpha /(1-\alpha)$

$\mathrm{t}$-statistics in parentheses

$* * * \mathrm{p}<0.01, * * \mathrm{p}<0.05, * \mathrm{p}<0.1$ 


\begin{tabular}{|c|c|c|}
\hline $\begin{array}{l}\text { Dependent } \\
\text { variables }\end{array}$ & $\begin{array}{c}(1) \\
\text { D. } \ln Y H \\
\end{array}$ & $\begin{array}{c}(2) \\
\text { D. } \ln \mathrm{AH} \\
\end{array}$ \\
\hline Workforce aged 55-64 & $\begin{array}{c}-0.280 * * * \\
(-3.636)\end{array}$ & $\begin{array}{l}-0.260 * * \\
(-2.425)\end{array}$ \\
\hline Old age dependency ratio & $\begin{array}{l}-0.386 \\
(-1.281)\end{array}$ & $\begin{array}{c}-0.661 \\
(-1.583)\end{array}$ \\
\hline Youth dependency ratio & $\begin{array}{l}-0.0282 \\
(-0.149)\end{array}$ & $\begin{array}{c}-0.204 \\
(-0.772)\end{array}$ \\
\hline External instruments & $\begin{array}{l}\text { 10-year lagged population } \\
\text { proportions }\end{array}$ & $\begin{array}{l}\text { 10-year lagged population } \\
\text { proportions }\end{array}$ \\
\hline County fixed effects & Yes & Yes \\
\hline Year fixed effects & Yes & Yes \\
\hline Observations & 608 & 598 \\
\hline Number of countries & 22 & 22 \\
\hline Workforce aged 55-64 & $\begin{array}{c}-0.597 * * * \\
(-4.488)\end{array}$ & $\begin{array}{c}-0.755^{* * *} \\
(-4.119)\end{array}$ \\
\hline Dependency ratio (combined) & $\begin{array}{c}-0.784 * * * \\
(-2.921)\end{array}$ & $\begin{array}{c}-0.426 \\
(-1.150)\end{array}$ \\
\hline External instruments & $\begin{array}{l}\text { Births } 10,20,30, \\
\text { and } 40 \text { years ago }\end{array}$ & $\begin{array}{l}\text { Births } 10,20,30 \text {, } \\
\text { and } 40 \text { years ago }\end{array}$ \\
\hline County fixed effects & Yes & Yes \\
\hline Year fixed effects & Yes & Yes \\
\hline Observations & 373 & 373 \\
\hline Number of countries & 21 & 21 \\
\hline
\end{tabular}

t-statistics in parentheses

${ }^{* * *} \mathrm{p}<0.01,{ }^{* *} \mathrm{p}<0.05,{ }^{*} \mathrm{p}<0.1$ 


\begin{tabular}{lccccc}
\hline & Table 4. Controlling for the entire age distribution & \\
\hline $\begin{array}{l}\text { Dependent } \\
\text { variables }\end{array}$ & $(1)$ & $(2)$ & $(3)$ & $(4)$ & $(5)$ \\
\hline & D.lnYW & D.lnKY & D.lnHC & D.lnA & D.lnAH \\
Workforce aged 30-39 share & -0.0805 & 0.0190 & 0.00868 & -0.115 & -0.0618 \\
& $(-0.989)$ & $(0.594)$ & $(0.586)$ & $(-0.959)$ & $(-0.870)$ \\
Workforce aged 40-49 share & -0.00537 & 0.0130 & 0.0145 & -0.0437 & $-0.324^{* *}$ \\
& $(-0.0490)$ & $(0.325)$ & $(0.710)$ & $(-0.293)$ & $(-2.143)$ \\
Workforce aged 50-54 share & -0.0123 & -0.0543 & 0.00513 & 0.0308 & $0.406^{* *}$ \\
& $(-0.0524)$ & $(-0.644)$ & $(0.221)$ & $(0.0968)$ & $(2.544)$ \\
Workforce aged 55-64 share & $\mathbf{- 0 . 2 3 7 * *}$ & $\mathbf{0 . 0 8 8 7 * * *}$ & $\mathbf{0 . 0 0 7 1 7}$ & $\mathbf{- 0 . 3 4 6 * *}$ & $\mathbf{- 0 . 5 6 2 * * *}$ \\
& $\mathbf{( - 2 . 3 7 3 )}$ & $\mathbf{( 3 . 0 7 9 )}$ & $\mathbf{( 0 . 3 3 1 )}$ & $\mathbf{( - 2 . 6 9 1 )}$ & $\mathbf{( - 4 . 1 5 2 )}$ \\
Old age dependency ratio & 0.0365 & -0.0609 & $-0.0655^{* *}$ & 0.186 & 0.242 \\
& $(0.222)$ & $(-1.098)$ & $(-2.108)$ & $(0.786)$ & $(0.810)$ \\
Youth dependency ratio & -0.0343 & 0.0191 & 0.0153 & -0.0550 & 0.112 \\
& $(-0.309)$ & $(0.451)$ & $(0.849)$ & $(-0.333)$ & $(0.729)$ \\
Intercept & & & & 0.0693 \\
& 0.0621 & -0.00366 & 0.00603 & 0.0604 & 0.0693 \\
Country fixed-effects & $(0.995)$ & $(-0.156)$ & $(0.666)$ & $(0.681)$ & $(1.021)$ \\
Year fixed-effects & Yes & Yes & Yes & Yes & Yes \\
Observations & Yes & Yes & Yes & Yes & Yes \\
Number of countries & 642 & 661 & 661 & 642 & 573 \\
\hline
\end{tabular}

$\ln \mathrm{KY}$ is adjusted with $\alpha /(1-\alpha)$

t-statistics in parentheses

$* * * \mathrm{p}<0.01, * * \mathrm{p}<0.05, * \mathrm{p}<0.1$ 


\begin{tabular}{|c|c|c|c|c|c|c|}
\hline \multicolumn{7}{|c|}{ Table 5. Effects of Policies } \\
\hline Dependent & (1) & (2) & (3) & (4) & (5) & (6) \\
\hline variables & D. $\ln A$ & D. $\ln A$ & D. $\ln A$ & D. $\ln A$ & D. $\ln A$ & D. $\ln A$ \\
\hline Workforce aged 55-64 (W55-64) share & $\begin{array}{l}-1.338^{* *} \\
(-2.308)\end{array}$ & $\begin{array}{c}-0.590 * * * \\
(-3.610)\end{array}$ & $\begin{array}{c}-0.608^{* * *} \\
(-4.676)\end{array}$ & $\begin{array}{c}-0.198^{* *} \\
(-2.783)\end{array}$ & $\begin{array}{c}-0.656^{* *} \\
(-2.810)\end{array}$ & $\begin{array}{l}-0.340^{*} \\
(-1.933)\end{array}$ \\
\hline W5564*Lagged physician density to population & $\begin{array}{l}0.342 * \\
(1.890)\end{array}$ & & & & & \\
\hline Lagged physician density to population & $\begin{array}{c}-0.0774 * * \\
(-2.610)\end{array}$ & & & & & \\
\hline W5564*Lagged public sector spending on R\&D (in GDP) & & & & & $\begin{array}{c}1.566^{* *} \\
(2.113)\end{array}$ & \\
\hline Lagged public sector spending on R\&D (in GDP) & & & & & $\begin{array}{l}-0.133^{*} \\
(-1.868)\end{array}$ & \\
\hline W5564*Lagged private sector spending on R\&D (in GDP) & & & & & & $\begin{array}{l}0.0683 \\
(0.481)\end{array}$ \\
\hline Lagged private sector spending on R\&D (in GDP) & & & & & & $\begin{array}{c}-0.00744 \\
(-0.297)\end{array}$ \\
\hline W5564*Labor market reform dummy (Reduction in EPLR) & & & & $\begin{array}{c}0.159 \\
(0.994)\end{array}$ & & \\
\hline Labor market reform dummy & & & & $\begin{array}{l}-0.0106 \\
(-0.606)\end{array}$ & & \\
\hline W5564*ALMP reform dummy (Increase in ALMP on training) & & $\begin{array}{c}0.351^{* *} \\
(2.328)\end{array}$ & & & & \\
\hline ALMP reform dummy & & $\begin{array}{l}-0.0242 \\
(-1.411)\end{array}$ & & & & \\
\hline W5564*Tax wedge reform (Reduction in tax wedge) & & & $\begin{array}{c}0.403^{* *} \\
(2.301)\end{array}$ & & & \\
\hline Tax wedge reform & & & $\begin{array}{c}-0.0389^{*} \\
(-2.063)\end{array}$ & & & \\
\hline Intercept & $\begin{array}{c}0.326^{* * *} \\
(3.656)\end{array}$ & $\begin{array}{c}-0.260 \\
(-1.565)\end{array}$ & $\begin{array}{c}0.0893 * * \\
(2.136)\end{array}$ & $\begin{array}{l}-0.0382 \\
(-0.458)\end{array}$ & $\begin{array}{l}0.0596 \\
(1.108)\end{array}$ & $\begin{array}{l}0.0325 \\
(0.532)\end{array}$ \\
\hline Country fixed effects & Yes & Yes & Yes & Yes & Yes & Yes \\
\hline Year fixed effects & Yes & Yes & Yes & Yes & Yes & Yes \\
\hline Observations & 354 & 262 & 301 & 479 & 522 & 485 \\
\hline Number of countries & 18 & 20 & 18 & 22 & 22 & 21 \\
\hline
\end{tabular}

t-statistics in parentheses

${ }^{* * *} \mathrm{p}<0.01,{ }^{* *} \mathrm{p}<0.05,{ }^{*} \mathrm{p}<0.1$ 


\section{Appendix}

\begin{tabular}{|c|c|c|c|c|c|c|}
\hline $\begin{array}{l}\text { Dependent } \\
\text { variables }\end{array}$ & $\begin{array}{c}(1) \\
\text { D.LFPR1519 }\end{array}$ & $\begin{array}{c}(2) \\
\text { D.LFPR2029 }\end{array}$ & $\begin{array}{c}\text { (3) } \\
\text { D.LFPR3039 }\end{array}$ & $\begin{array}{c}(4) \\
\text { D.LFPR4049 }\end{array}$ & $\begin{array}{c}(5) \\
\text { D.LFPR5054 }\end{array}$ & $\begin{array}{c}(6) \\
\text { D.LFPR5564 }\end{array}$ \\
\hline $\begin{array}{l}\text { Labor productivity growth } \mathrm{t}-1 \\
\text { (output per worker) }\end{array}$ & $\begin{array}{l}0.0372 \\
(1.106)\end{array}$ & $\begin{array}{l}0.0360 \\
(0.642)\end{array}$ & $\begin{array}{l}0.0317 \\
(0.853)\end{array}$ & $\begin{array}{l}0.0292 \\
(1.221)\end{array}$ & $\begin{array}{r}-0.00907 \\
(-0.290)\end{array}$ & $\begin{array}{c}0.119^{* * *} \\
(4.360)\end{array}$ \\
\hline Intercept & $\begin{array}{l}0.00454 \\
(0.295)\end{array}$ & $\begin{array}{l}-0.0176 \\
(-0.685)\end{array}$ & $\begin{array}{c}-0.00578 \\
(-0.344)\end{array}$ & $\begin{array}{l}-0.000853 \\
(-0.0563)\end{array}$ & $\begin{array}{l}-0.0101 \\
(-0.510)\end{array}$ & $\begin{array}{c}-0.00318 \\
(-0.255)\end{array}$ \\
\hline Country fixed effects & Yes & Yes & Yes & Yes & Yes & Yes \\
\hline Year fixed effects & Yes & Yes & Yes & Yes & Yes & Yes \\
\hline Observations & 691 & 691 & 669 & 644 & 644 & 681 \\
\hline Number of countries & 24 & 24 & 24 & 24 & 24 & 24 \\
\hline
\end{tabular}

\begin{tabular}{|c|c|c|c|c|c|c|}
\hline $\begin{array}{l}\text { Dependent } \\
\text { variables }\end{array}$ & $\begin{array}{c}(1) \\
\text { D.LFPR1519 }\end{array}$ & $\begin{array}{c}(2) \\
\text { D.LFPR2029 } \\
\end{array}$ & $\begin{array}{c}(3) \\
\text { D.LFPR3039 } \\
\end{array}$ & $\begin{array}{c}(4) \\
\text { D.LFPR4049 }\end{array}$ & $\begin{array}{c}(5) \\
\text { D.LFPR5054 }\end{array}$ & $\begin{array}{c}\text { (6) } \\
\text { D.LFPR5564 }\end{array}$ \\
\hline $\begin{array}{l}\text { Labor productivity growth } \\
\text { t-1 } \\
\text { (output per hour) } \\
\text { Intercept }\end{array}$ & $\begin{array}{l}0.0933 * * \\
(2.257) \\
-0.0251 \\
(-1.599)\end{array}$ & $\begin{array}{c}0.0704 * * * \\
\\
(2.645) \\
0.00838 \\
(0.828)\end{array}$ & $\begin{array}{l}0.0102 \\
(0.235) \\
-0.0101 \\
(-0.613)\end{array}$ & $\begin{array}{c}0.0237 \\
(1.008) \\
-0.00229 \\
(-0.185)\end{array}$ & $\begin{array}{l}0.00993 \\
(0.291) \\
0.00593 \\
(0.329)\end{array}$ & $\begin{array}{l}0.111 * * * \\
\\
(4.215) \\
-0.0132 \\
(-1.316)\end{array}$ \\
\hline $\begin{array}{l}\text { Country fixed effects } \\
\text { Year fixed effects } \\
\text { Observations } \\
\text { Number of countries } \\
\end{array}$ & $\begin{array}{c}\text { Yes } \\
\text { Yes } \\
609 \\
24 \\
\end{array}$ & $\begin{array}{c}\text { Yes } \\
\text { Yes } \\
609 \\
24 \\
\end{array}$ & $\begin{array}{c}\text { Yes } \\
\text { Yes } \\
609 \\
24 \\
\end{array}$ & $\begin{array}{c}\text { Yes } \\
\text { Yes } \\
583 \\
24 \\
\end{array}$ & $\begin{array}{c}\text { Yes } \\
\text { Yes } \\
583 \\
24 \\
\end{array}$ & $\begin{array}{c}\text { Yes } \\
\text { Yes } \\
609 \\
24 \\
\end{array}$ \\
\hline
\end{tabular}

$\mathrm{t}$-statistics in parentheses

$* * * \mathrm{p}<0.01, * * \mathrm{p}<0.05, * \mathrm{p}<0.1$ 


\begin{tabular}{lccc}
\hline \multicolumn{3}{c}{ Table A3. Instrumentation equations using lagged population proportions } \\
\hline & W5564 ratio & $(2)$ & $(3)$ \\
& $1.345^{* * *}$ & OADR & 0.075 \\
& $(11.60)$ & -0.114 & $(0.95)$ \\
\hline Population share $45-54 \mathrm{t}-10$ & $0.237^{*}$ & $(1.31)$ & $-0.292^{*}$ \\
& $(1.81)$ & $0.997^{* * *}$ & $(1.81)$ \\
Population share 55-59 $\mathrm{t}-10$ & $(9.95)$ & $1.653^{* * *}$ \\
& 0.273 & $-0.720^{* * *}$ & 0.075 \\
Population share 00-04 t-10 & $1.345^{* * *}$ & -0.114 & 679 \\
& 679 & 679 & 22 \\
Observations & 22 & 22 & 174.96 \\
No of countries & 45.51 & 47.23 & \\
F-stat first stage & $\mathrm{t}$-statistics in parentheses &
\end{tabular}

Table A4. Instrumentation equations using lagged birth variables

\begin{tabular}{lcc}
\hline & Table A4. Instrumentation equations using lagged birth variables \\
\hline & W5564_ratio & $(2)$ \\
& $-0.043^{* * *}$ & Dependency ratio \\
\hline Birth number $t-40$ & $(4.76)$ & -0.005 \\
& $-0.064^{* * *}$ & $(1.15)$ \\
Birth number $t-30$ & $(8.87)$ & $-0.039^{* * *}$ \\
& $-0.040^{* * *}$ & $(11.98)$ \\
Birth number $t-20$ & $(5.37)$ & $-0.020^{* * *}$ \\
& $-0.062^{* * *}$ & $(5.92)$ \\
Birth number $t-10$ & $(8.32)$ & $0.025^{* * *}$ \\
& 391 & $(7.35)$ \\
\hline Observations & 21 & 391 \\
No of countries & 39.68 & 21 \\
F-stat first stage & & 73.56 \\
\hline
\end{tabular}

$\mathrm{t}$-statistics in parentheses

$* * * \mathrm{p}<0.01, * * \mathrm{p}<0.05, * \mathrm{p}<0.1$ 